\title{
Creating an Entrepreneurial Generation, the Training of Human Capital: The Relationship of Economic Growth and Development
}

\author{
Necmettin Şahin, Yaşar Nari \\ Gediz University, Izmir, Turkey
}

\begin{abstract}
Nowadays, the competitive economic system rules has given its place to an innovative perception that produces ideas based on knowledge instead of the entrepreneurship perception that wanted to make profit by means of taking risk based on courage. The entrepreneurship concept which is in a constant change depending upon time and conditions confronts as an entrepreneurship concept based on innovation has gained importance as a result of the knowledge which has been regarded as goods with the transition from industrial society to knowledge society. From now on, individuals, their knowledge, their abilities generating added value and the qualifications of human capital in the process of developing of societies take an important place in realizing the social purposes. In this study, it is emphasized on the importance of the training strategy in strengthening human capital, the reintroducing of the knowledgeable and self-confident entrepreneurial individuals to society, and their impacts on the development process of the country.
\end{abstract}

Keywords: human capital, training strategy of entrepreneurial generation, economic growth and development process

The politics of liberal politics basing on private enterprise was preferred during establishment of Turkish Republic. In February 1923, according to the decisions of principles taken in the Congress of Economics in Izmir, the effectuating of a group of businessmen and merchants from Turks and Muslim residents had officially continued until 1930s. The required organizational and institutional legislations had been arranged by states themselves, in order to be able to provide the continuous functioning of market economics. Yet, by the collapse of international financial system due to the effects of classical liberal paradigm, the world economic crisis in 1929 and the loss of reliance on the policies of classical free market economics represented by slogans announcing "Let them do, let them pass by" and the increase in the statist paradigm of Keynes, the change in the monetary direction of Turkey on the side of statism has been observed. During these years of directional change, the increase in the monetary enterprises of state emerged.

After 1930s, both the lack of capital and the lack of qualified labor with absence of entrepreneurship in

Corresponding author: Necmettin Şahin, Yrd. Doç. Dr., associate professor, Vocational School, Management Administration Programme, Gediz University; research fields: management economy, macro economy, and social economy. E-mail: necmettin.sahin@gediz.edu.tr.

Yaşar Nari, Ph.D., teaching assistant, Director of Vocational School, Gediz University; research fields: history and public management. E-mail: yaşar.narı@gediz.edu.tr. 
Turkey, which could be named as the insufficiency of economic conditions, prevented the development of the ability of private entrepreneurship. In this period, the state was obliged to supply the need of public, where the power of private entrepreneurship failed to compensate. The policy of the producing the equivalent products, which was not officially free to import until 1950s, continued partly the existence of partial liberalisation applications between 1950 and 1960; and by the beginning of 1961, the private entrepreneurship and the competitive policies were left to second plan in practice by the planned development politics until the decisions of January 24, 1980. The policies of closed and incompetitive equivalent good policies against import products hindered the improvement of the real value adding contributions of free entrepreneurship that may support the creation of economic values in Turkey.

With the decisions of January 24, 1980, the alterations in international dimensions were observed in the development process of the international competitive economies. Today, due to the rapid improvements in technology, the properties and characteristics of services and commodities gradually increase. Moreover, the necessity of having information in changing environment gradually escalates and generates a pushing power to gain an international dimension for small entrepreneurs. As a result of increased competition and improved marketing methods, the consumers are able to choose the services and products from lots of different cultures and countries.

The differences in the preferences of consumers, the changes in behaviours of consumers pushed investors to direct their sources to foreign markets. By means of the effects of the new investments held in the international markets, the Turkish investors got the position of a being player in foreign markets. It is essential for the Turkish investors to create new market fields by taking the advantage of new markets in international environment. Yet, it is required for entrepreneurs to build their competitive characteristics about improving their knowledge about the conditions of international business environment and the politics and differences in target market.

From the perspectives of all countries, the building up of a well-educated society for future has to be a strategic purpose. In a global perspective, the development level of countries is measured by depending on the dimension of capability of producing information, transformation of the information to the technology and the superiority in international market. In this research, the human resource, which has self-confidence to change future, risk taking characteristics, futuristic point of view and innovative, is required. We would like to analyse the approaches of the individuals, who are going to fulfill the requirements of information, technology, innovation, and education.

Lots of index and criteria are being used at the classification of the entrepreneurship and wealth. Additionally, the youth of the communities open to competition and their ability to achieve value added activities are outshined. The getting this kind of capability can be possible by the generation of information community after the shaping of industry community, the superiority in production under the conditions of competition and the trading of the commodities produced. The increasing level of modern society would gain speed by depending on the production of information, its effectiveness in usage and sharing among members. Due to the fast production of information in our age, its spreading and usage by parties, the conditions of productive functions and employment change rapidly. The speed of cycle pushing the freedom in factorial roaming can also effect the decisions and skills of entrepreneurship.

This study was structured on the strategy of training of open-minded, highly utilized, flexible, dynamic, disciplined, honest and safe forward looking generations. The authors also aimed to clarify the relations among 
strategies and targets of improving of individual and social capital, sources shared for education as "development currency", and targets of wealth economies. In addition to this approach, the correlation among information, new product, and the idea of entrepreneur individual, technological improvement and education of individuals were tried to be evaluated.

\section{The Strategy of Human Capital Education and Economic Development}

The human source is the most important component in improving the technology and the economic development of the countries while increasing the efficiency. Development in a country, investment on education and education policies over development carry out a strategic purpose of a regular social alteration. Human capital described as the "source of human", therefore, stands for very well-skilled and well-educated individuals. Sufficiently trained humans and tangible capital are the supplementary components of each other as power of production in an economic development. The higher educated and more skilled profiles of the humans are regarded as the value adding components of human source.

According to Adam Smith, the fundamental of the economic growth lies in the division of labor and becoming a professional in the market. As long as the labor increases its specialization over a specific field that it will get a better knowledge of practice than other competitors and will act better in the market by doing his job more efficiently. This will also affect the economic growth while improving the social well-fare positively (Karadeniz, 2007, pp. 20-21). The characteristics of entrepreneur, which can be shaped by the specialization oriented trainings, will constitute the "human source" in terms of risk-taking, innovative, capable of using technology, and opportunity-oriented. For that reason, Shultz regarded the expenses for education as the most valuable investments and stated that education had producing and consuming sides as well. The money spent for education by individuals shows the consumption part of education, whereas the efficiency of the educated individuals and their efforts to support for the economic development point out the producing part of the education (Bozkurt \& Doğan, 2003, p. 195).

The basic purpose of the development is not only gaining wealth in meaning of economics, but also to make richness and wealth sustainable components by training qualified human source for continually. The investments on these fields increase the significance of expenditures for future generations in the content of education, health, nutrition, and environment. From the perspectives of the "science of economics" in classical literature of the economics in the evaluation of the individual capital and economic productivity, the social scientists like A. Smith, Denison, Schultz, and Baker emphasize that the most important investment would be named as education. According to the approach of Prebish Singer, who explained the relation among labor, individual capital and efficiency, the education investments which are going to strengthen individual capital, are not subject to law of decreasing efficiencies. On contrary, they are subject to law of increasing efficiency. Wasilly Leontief defines labor as being inspected under two titles: qualified labor and uneducated labor supported by physical power by.

From the economic point of view, education is both a product of consumption and a component of production. Education is a consumption product because of being used independently, desired and demanded value. A relation can be pointed out between the component of education and the socio-economic contribution done for stock of individual capital. As the purpose of education is not only to structure the tangible capital, but also to shape human behaviours in positive direction, upon which the utility for society would be provided. The cost and utility of education is related with economic and social development of country. 
When the internal growth economists, who drifted away from the forecast about the decreasing profit of capital, gains a human or company capital that directs the monopoly oriented firms (where innovation is created) to tendency of producing more value as innovation. By this approach, the sources of economic development are being defined as technology, information, and human capital. According to this point of view, each new investment brings innovation and information together with. The mid-point of internal development theories is standing over the properties internalization through human source and R\&D (research and development). Economic development and human capital during the process of development were concretized in shape of capital stock by Romer and information was thought as net additional investment. According to this approach, the most important component for development is labor.

Structural models, in which the capital of human is internalized, by means of externalizing the human capital, it is expected to affect the increase the GDP (gross domestic product) in long term. The human capital is skilled and educated labor. The component that increases the active labor is the knowledge. The analyses show that the countries which have an intensive human capital develop more rapidly than the others. Several economic development models express that it is only possible to increase the human capital through education. It is highly regarded that the money invested on education differentiated from the others, such as the investments that help the development in a country such as health, nutrition, as it gets the most beneficial investment. In socio-economic analyses, the authors have difficulties to measure the investments on education. According to Nelson and Pelps, if a country has a great deal of the human capital, it becomes easy for that country to apply the new inventions and developments efficiently.

However, a country remains as a country that imitates the innovations and the new developments, this causes the easy adaptation of the new technologies and the rapid improvement and development of that country. According to Lucas, the improvement of human capital is directly related with the education level of labor. In other words, investments for human capital are the investments made for both formal education and training of employees in business environments. The human capital ratio will increase when a rise in the period of the investment on the human capital is done. Apart from this point, if a country has a production that causes learning by means of practicing, the development rate will be affected positively from this situation. For Barro, education directly determines the development which has a parallel effect in the birth rate and the amount of the physical investment. He also clarifies that the increase of the education period will affect the physical investment.

\section{The Condition of a Country's Population Structure in International Competition}

There is a strong relation between capacity of population of county and its classification. The basic factors of developing a country are labor and the characteristics of labor, which display gaining or loss of speed of development. By depending on this point of view, the most important factor in developing of an economy is educated human capital (individual capital). Individual capital is formed through the improvement of knowledge, skills, and emotional factors; in other words, it is formed by means of education. In the success-oriented projects, the main target is to form a capacity and keep its sustainability in the target audience. The size of the population in a country, its structure, and rapid growth are the significant components for the economic development. The structure of the country's population and its quantity form up the demand of the labor. Also, the amount of the population affects the level of income per capita.

The increase in characteristics of labor represents an important source of the rise in GNP (gross national product). The main target in theoretical researches which explain the structure and effects of labor over 
production is decreasing the differences among ability, experience, and education, and improving the strategies focusing on the efficient usage of capital and individuals of society.

According to the employment theory of school of classical economics, it has been considered that the labor grows up by being non-homogenous, as a stable percentage of population and with a constant speed sourcing from external structures. From the perspective of one of the pioneers of the school of classical economics, R. Malthus, who developed the theory of "Population Trap", the population of the world has been doubled in a geometric slope, while the livestock and production of food arithmetically inclines. In order to solve this problem, Malthus offered the moral hindrances that may be brought to the private life of people, like limitation of having children and giving support on living as singles or thinking about a late marriage.

Otherwise, Malthus defended the thesis of drifting of humanity in to a catastrophe in case of low-income ratios confronting the increased food prices. By low income level and balance trap theory, the relation between increase in population and increase in income ratios are tried to be explained. According to this rule, in the economies where the low income level is valid, the reason for the increase of population is the decrease in death rates. As a result, as the income for per capita increases, the level of death due to environmental factors decreases as well. As a result, the population increases as the income per capita increases rapidly. At the beginning, in order to get an average level for the living standards, the increase speed of the income ratio needs to be faster than the population increase speed. The balance that has been met at a point is regarded as a decisive balance and this shows the level of the income, the average living standards, and low income level and balance trap. The issues that show the development of the countries' population structure (such as birth and death rate, immigrations and emigrations, the education level of the age groups and labor force) inform us about a country's social and economic development.

Economic structure, at first, shifts from agriculture to industry, and in aftermath to services. The developments in industry and services increase the demand on educated labor. In most of the developed countries, through the demographic passage period, the population does not increase or increases with a slow movement. As observed in the conditions of developing countries, like Turkey, have both high rate of death and the high birth rates because of demographic passage process at the same time. While the development strategies with education plans are implemented, it is required also to target the real development of population.

Nowadays, the affording of countries in developing and growing must be taken in to consideration as complete action of strengthening individual capital. The most of the planning studies made on this field needs to explain ideal population ratio as the ratio that maximizing the income per capita. In our age, the countries, which are over the optimum level of population, have low income per capita and their decreasing level in income because of inefficient consumption of resources, and on the contrary, the low rate populated countries are complaining about having difficulties in finding qualified work force in spite of keeping higher income level per capita. The success level of economics is measured by the employment of the population at desired level.

One of the most important obstacles faced by the countries that growing and developing on this process is the lack of employment and the problem of unemployment. The problem of not being able to provide work place for the population is mostly sourcing from the insufficient structures of the economies. Because of the fast increase in population rate, availability of work places for new coming generations must be prepared in parallel to the economic growth. 


\section{Entrepreneurship and the Economical Dimension of the Entrepreneur Individual as a Production Factor}

In the 16th century, with the effects of mercantilism, the countries took place in a competition of exporting the commodities of private and public entrepreneurship to import silver and gold. With the beginning of this stream in economics, the salvation of big industrial institutions formed up. After the mercantilist approach and with the emergence of liberalism, continuity of competition at high level and supporting of international trade had increased the importance of private entrepreneurship, as it began to be emerged in Europe. In addition to these developments, it can be said that the risk factor in entrepreneurship was seen for the first time in the 17th century (Ercan \& Gökdeniz, 2009, p. 61).

The concept of entrepreneurship is based on the capitalist market economy approach of Adam Smith and classical school. According to Smith, the capitalist is the one, who brings work force, industry, and agriculture together in an effective way. According to this definition, the characteristics of entrepreneur and capitalist remain same with each other. In classical economics, the concept of entrepreneurship came up with the approaches of Baptiste Say in widest meaning (Peneder, 2009, p. 80). Say saw economic development as a conclusion of entrepreneur activity and evaluated entrepreneur like Cantillon by claiming about entrepreneur as the one taking own risk by investing own capital. Say, himself, is also an entrepreneur and the first person who explained the definition of entrepreneur in modern concept (Filion, 1997, p. 2). In liberal capitalist understanding, the profit-oriented earning desire depending on the competition was supported by the pushing effect of entrepreneurship.

In neo-classic theory, entrepreneurship is a derivation of characteristics of competition market. When these properties are observed, it is seen that there are lots of retailers and buyers in market who are not able to dominate the market and aware of the developments taking place in market environment at the same time. In such kind of economies, the protection of individuals and production from risks are mostly limited. Schumpeter's innovation model developed the basis of entrepreneurship in recent history. According to the J. Schumpeter's capitalist system where it faced with economic depression at the point of the dynamics of the capitalist entrepreneur; it leans on the human need that is based on continuous development. Entrepreneurial behavior that keeps the capitalist system embodies the five main features in Schumpeter's thesis.

Schumpeter developed these features: a new property or a new type of service or quality of the launch, implementation of new production techniques, different and new market presence, restructuring according to the technological structure of the industry, different raw materials or semi-finished sources of the entrepreneurial approach based on innovations. According to Schumpeter, because of the innovations which are substituted in other markets or destruct the several markets, this caused the new market getting more narrows and in the meantime, this new market could find a new way to find new companies into itself which has a "converter effect".

The entrepreneur, for Richard Cantillon, gets everyday goods from farmers over a certain price on the market and aims to profit by selling at uncertain prices brought to the city from buying. In doing so, the prices of farmers' markets in the city, where the property is acquired by the entrepreneurs take risks in the face of uncertainty, which has increased due to lack of predetermined forward direction or the assumed risk. Entrepreneurship is one of the cases information from the industrial society, which has become important in the transition to the community. The number of the individual entrepreneurs needs to be increased and their 
entrepreneurship skills should be trained while strengthening the human capital, the implementation of new business ideas and new established businesses.

Max Weber defines the entrepreneurial powerful capitalist people and the use of the entrepreneurial potential in other countries, by establishing a particular relationship between the capitalist and the Protestant ethic in order to explain the basic social value system of entrepreneurs through the mentality of faith axis. Moreover, McClelland places the economic development in the relationship of the belief system between the parents and the independent behaving of the children.

To sum up, while creating change and technological innovations with new products, services and new processes figuring out important economic values and the factors that play active roles in the creation of new sources of supply and new markets the individuals carrying the entrepreneurial traits emerge as the active figures.

\section{Human Social Capital, Entrepreneur Individual, and Their Relationship System}

In recent years, economic development, entrepreneurship, providing employment began to be considered as the main factor of social development. In this information age, creating economic value for human beings is with more brainpower than physical strength. While rapid developments in science and technology are shaping with the structure of society in the era; it also forms the perspective of the entrepreneurship as a part of and increases the importance of entrepreneurship as well. The contemporary entrepreneurship in the society of the information affected by the developments of society can be described as the knowledge-based entrepreneurship ${ }^{1}$.

The country's strategy on education should be based and aimed to train on the economic factor of the labor, and open the generations who are open to innovation with knowledge, flexible, dynamic, disciplined, and honest can face the future with confidence. Developed countries locate much of their developments on keeping pace with new knowledge and technology, educational institutions, teaching children the knowledge-based technology, and preparing them according to the needs of the era. The common purpose of the customary skills and methodological strategy, in all of the traditional and modern societies, are raising awareness and increasing the sense of responsible people.

For the continuity of economic development, to be equipped within formation that will allow to maximize the performance of individuals as human capital is required to be trained. Therefore, training in the formation of human capital as an important factor involved in the first degree is encountered. Indeed, Easterlin, who claims that education is associated with technological change, expresses that technological diffusion behind the economic growth of a significant population of "formal education system" with the appropriate characteristics and motivations stated that is due to the acquisition level. South Korea, Taiwan, and Singapore that showed a rapid economic development and gave way to the Asian miracle have given importance to primary and secondary education, and they imposed the compulsory education period up to nine years. In addition, these countries also supported to improve the quality of education and higher education. In today's economy of the knowledge, the process of the education emerged as the eternal movement which emphasized the life-long learning education and training philosophy (Karadeniz, 2007, pp. 14-15).

In human resources management, during the formation of the structure of labor demand, it is known that the individuals who are prone to work in a team, are capable of deriving information by means of information,

${ }^{1}$ Retrieved from http://girisimcilik.mu.edu.tr/. 
have pure self-conscience, and domestic entrepreneurs will be chosen as employees. For the education of these people on this purpose, educational curriculums must be developing and have the consistent flexibility that can be shaped through needs in a country. Graduate students are considered as educated and ready for production in developed societies.

It is also aimed that young people educated in universities, have the ability to set up their own business and providing entrepreneur generations. These young people who are educated at universal norms are considered to contribute to the economy of the country by means of various achievements at domestic and international entrepreneurship. Therefore, in our country, it is necessary to consider each student that starts university, not as a candidate looking for a job in the public sector, but as a candidate of an entrepreneur who can start their own business.

In this context, today's youth must be grown up not as a "job seeker" but someone who "is seeking to set up their own business or searching ways for this". The educations in the universities, scientific studies, and encouragements are important contributions to this process.

Especially with a young population and a student like us, assigning the step to college "perspective of entrepreneur" with the look and university students are required to gain the mission ${ }^{2}$.

The relationship between the human and social capital investment objectives that will develop training strategies and training resources allocated should be considered different from investment in other sectors. Intrinsic growth theories, giving priority to technologies and changing assumptions of neo-classical approach have made a major contribution to the economics literature. In recent years, human capital is considered as an important determinant of economic growth. With the increase of the importance of human capital, besides the classical production factors, this caused development policies to be reconsidered. Physical capital alone is no longer adequate in explaining economic growth. For that reason, in the economic development process for the effective usage of not only the physical capital but also the human capital, necessary measures should be taken into consideration (Author, Gökmen, 2009). Returning of the sources used in the education process takes too much time in placing them in the economy. Educational investments are considered as a high-cost but a sustainable investment that can be a refundable "current development" in the development of economy.

In education curriculums, teaching process should not be directed to memorization and immitation. Starting from the childhood, to question the facts and events as well as searching ability of the cause-effect relationships with a great self-confidence should be developed in the individuals in order to be a self-confident individual. We cannot speak of a simple life cycle for the contemporary man. It can be easily pointed out that we need an educational system that can bring in the methods of debate, analyzing and finding a solution while confronting a difficulty and in a complex system. This system helps the individual to learn the required learning skills and methods while solving problems and understanding the world.

\section{The Economy of Knowledge and Its Relationship With the Technology}

Human capital is defined briefly as the sum of the knowledge and skills possessed by the labor involved in the production. In other words, to have individuals involved in the production process and emphasizes the nature of human knowledge, skills, experience and dynamism as positive values are considered as human capital (Atik, 2006, p. 6). With the Renaissance, it is observed that human beings started to direct science, manufacture new products according to his needs and continuously manufacture mass production. Historians of

${ }^{2}$ Retrieved from http://girisimcilik.mu.edu.tr/. 
the economy who defined the era as the "Industrial Revolution" in which the mode of mass-production caused such developments have paved the way for a major competition in domestic and foreign markets. Romer, a famous economist in 1986, who deals with knowledge of new products and entrepreneurial inventor individuals or firms and individuals in search of new ideas for technological developments, a result of new information seeking explains his opinion by his thesis: "If you combine it with capital, the knowledge and skills of diminishing returns will lose the effect of the law". Today, information has come to such a point that the identity of the processed products of science and technology gained and converted into economic goods. Entrepreneurs began to build the knowledge and use of technology and scale advantages of mass production facilities that can be used as soon as the economy. These developments in the production style have pushed the entrepreneurs into the seeking innovation and technological efficiency.

The machines that were involved in the production process and dropped the manufacturers off the competition have revealed the competition more effectively and on a larger scale. In this new competitive era, the technological knowledge that is adapted in the industry and the source of the information in this development has become inevitable to support the R\&D activities in the system.

The social welfare with the efficient use of production of the resources is directly related to the development of scientific and technological studies. So production efficiency can be captured in the quality of the human capital of the country. From the long-term growth perspective, Lucas defends that human capital is the most important factor of production and argues that physical capital is given more emphasis than the necessary capital. In his model, he added the single input to enhance the ability of time-labor households that is devoted to education and school buildings such as research laboratories and teaching services (Yumuşak \& Tuna, 2000, p. 7). Arrow defines the knowledge carried by the human factor which the source of production is as the goods. According to the Arrow, there are special qualities of knowledge. The protection of the knowledge from the third parties and more there is no cost to share information with the third parties as the knowledge is provided as public goods. The main task of a modern state administration is to identify systems and strategies to improve the welfare of the society. The realization of this goal is possible with the rapidly evolving scientific and technological progress, depending on the education system.

The effectiveness and the possibility of the use of existing production resources in the country can only be effective by providing a scientific thinking in the society as their life style. From the Arrow's argument, Romer assumes that technical knowledge is verified in the production and the investment period. For him, there are two entries: (1) creative ideas (innovative ideas): they are non-competitive goods; and (2) objects: are competitive goods (automobile, machine, telephone, television, and building). In addition, he thinks that the production knowledge is a non-competitive production of malt and technology is a non-competitive production factors. If the entry of competitive goods gets doubled, production will also get doubled. However, non-competitive goods do not have to be doubled in order to double the production. Therefore, it creates increasing returns. Finally, production of non-competitive goods and necessary knowledge for the production of these goods gives an acceleration in technological developments, and this affects the improvement positively.

This opinion is based on the idea that technological knowledge is a kind of capital goods. Technological knowledge cannot be completely consumed. By means of R-D and other facilities of creating the knowledge, it may be collected. In this case, the information is not contained in a kind of capital goods. Knowledge is a capital which can be used by anyone and is not subject to all returns. Knowledge (technological development) creates a spread on the economic units. Romer takes the knowledge as specific information related to a 
company and overall level in the society. The general level of knowledge in a society is equal to the sum of each company's information. If a firm's level of knowledge increases, the overall level of knowledge in society will increase. So everybody will get the benefit from the economy. In order to convert the production knowledge of the country to the production, it is related between the country's manufacturing sector and educational institutions that depends on the co-operation of the educational institutions and industry. This co-operation with the university of new production techniques and the industry structure from the other side to respond to the needs of different technologies of the industry and provides students the opportunity to practice in the field of academics. It is seen that new technical and theoretical knowledge in the real sector of the production process which is used and produced by universities in developed countries immediately turned into competitive power by creating additional added value. Development of educational institutions of the country competitive in the efficient use of limited resources in developing countries-industry cooperation is proposed to be adopted as a model. With the comprehension of the importance of educated manpower in the developing countries, the result of improving the investments on this field and efforts of forming a knowledgeable society, some countries direct themselves to achieve this by means of the educated man power ("brain power"). In the 1990s, Robert J. Barro has been made the most comprehensive study on human capital and economic growth. In Barro's work, the economic growth of the level of education has been determined that an additional annual increase by $0.44 \%$ (Karagül, 2003, p. 84 ).

In the theory of the internal growth, technology is an internal factor. The assumption that is expressed as technology is external is not realistic. In other words, pure convergence hypothesis as it is recognized that the realization of foresight in understanding the growth process being external to the technological developments that have a critical role in removing more closely by economists has become inevitable to be examined. This has led to new growth models, called internal growth (Kibritçioğlu, 1998, p. 216).

According to this approach, every company has its own R\&D activities, practicing by learning, knowledge in order to have its own technology. Unlike external growth models, technology is not standardized and equal. Companies protect their ownership of the technology that was produced by themselves throughout licensing and producing patents ownership interest in technology produced by patents and licenses because technological level of the country is regarded whether they are in the category of the developed countries according to the $\mathrm{R} \& \mathrm{D}$ activities how they allocate resources for innovation, the number of the patents, owning and designing a new product.

Technology is the reflection of knowledge, culture, thought on the product. The knowledge as a result of which is improved and presented as a prototype by means of the techniques achieved after the experimental process in the laboratory and released as a product of a positive result represents a technological implementation process. This is a process of transformation products as technological knowledge. It is clear that the international economic performance criteria as per capita income level and employment rate basis when compared with developed countries in order to be closer to the developed countries should be substantially more innovative and productive. In addition, technological infrastructure is important in the development of entrepreneurship. It is known that technological innovation infrastructures make a ground for the entrepreneurs to develop innovations or converting these innovations into commercial products. R\&D activities are one of the inputs for the production of the technology in the countries. Not enough investing on the R\&D expenditure, as well as having non-sufficient R\&D employees, Turkey shows a poor performance in scientific and technological production. Low scientific production reduces the contribution to the economy of high 
technologies. In order to reach the level of developed countries, the required growth should be based on knowledge, a competitive and dynamic economy. The way to increase the competitiveness of the economy is building system that accelerates the transition to the social structure by providing more resources on research and development, promoting innovation and investing in a knowledge-based human economic. This system consists of the key elements of the competitive system such as education, science, technology, and innovation. The rise of one of these factors also means the rise of the rest. In this context, there is a total unity relation between science and education policies, technology and innovation policies, and more in most cases, educational policies includes the science, technology, and innovation policies.

\section{Entrepreneurship in the Strategy of the Development Depending on the Market Economy}

In today's market of aggressive catalysts, entrepreneurs are the people who organize and by balancing different skills while evaluating the things as an opportunity and overcoming the problems (whereas others regard such situations as chaos) (Kuratko \& Hotgetts, 1985). Entrepreneurs are said to be the production factor who take risks, monitor opportunities and evaluations, make innovations and new goods or services, production of existing resources with this innovation, the development of a new method of production, the creation of a new market, the most prolific and versatile functions such as finding a new source of raw materials and production and restructuring of consumption. We can easily evaluate the entrepreneurs while creating new ideas, transferring high-efficiency fields to the function of the low productivity areas of economic resources by transforming the business idea and implementation to create growing sector by increasing productivity in the sector by using new technologies such as acceleration of economic growth.

Having significant studies on entrepreneurship and innovation, according to Schumpeter's "New Model", the entrepreneur emerges as an element of human capital and with the progress and efficiency of the increase in specialization, the rise and progress of technology, technical knowledge, management and organization to increase the skills, the improvement of product quality, product diversification and consumer preferences effectively meet the optimal capacity of production, lower costs, reduced reflections on the cost of the price, the society of rising prosperity, the source of the full and effective use, the increase in consumer benefits, the improvement of income distribution, is proposed to provide for the establishment of a liberal economic order and participants. Any innovation substituting a previous product in the new market or reducing that product in the market significantly is called "creative destruction". While a sector is born, the other disappears (T. Chen \& S. Chen, 2001, p. 2).

The fading away of gas lamp from the market with the invention of the bulb, can be given as an example. Creative destruction is a never-ending process that continues permanently (Irazu, 2005, p. 83). Entrepreneurs force to increase the competition in the market or to increase the efficiency and effectiveness of their innovation, creating a basis for the competitive functioning of the market economy provides a variety of community welfare and consumer preferences with new and different products. According to the strategy of economic growth of the European Union, development and job creation is only possible with the competitiveness of enterprises mentioned in the Lisbon Strategy that expresses development of entrepreneurship and dynamism. This thesis is directly linked with the investment, innovation, and competitive economic growth, paving for the presence of entrepreneurship noted that the regulatory environment.

As a result, to increase the entrepreneurial development and international competitiveness in Turkey, accelerate economic growth, increase employment and flexible dynamics to improve the income and 
consideration, the construction of modern education and development strategy with innovation and knowledge should be given priority in the society. Changes in the legal infrastructure necessary for its economic, technological and educational policies, should be set targets in human capital and should be established to strengthen the axis. In this context, industrial R\&D incentives with the policies of science and technology, intellectual property regulations related to intellectual property rights, creating a budget for the entrepreneurs, creating capital and increasing the competitiveness by producing technology of individuals with education and making the necessary regulations for improving the welfare should be provided in our country. Entrepreneurship supports mechanisms and the development of incentives and the contribution of individuals to the community for the creation of an entrepreneurial climate, where entrepreneurship is supported on each platform and the public about the important role of emphasis on economic growth, should be established. Starting from the education process of the youth, entrepreneurship should always be encouraged to become a part of the entrepreneurship education...

\section{References}

Atik, H. (2006). Human capital, external trade and economic development. Bursa: Ekin Kitabevi.

Bozkurt, H., \& Doğan, S. (2003). The relationship between education and economic growth: A co-integration analysis for Turkey. II. National Knowledge, Economy and Administration Congress 2003, 193-202.

Chen, T., \& Chen, S. H. (2001). Global production networks and local capabilities. East-West Center Working Papers, Economic Series, No. 15, February.

Ercan, S., \& Gökdeniz, İ. (2009). Entrepreneurial development period and Kazakhistan from the entrepreneurial perspective, Bilig. Journal of Social Sciences of the Turkish World, Spring(49), 59-82.

Eser, K., \& Gökmen, Ç. E. (2009). Journal of Social Sciences and Humanities, 1(2).

Filion, L. J. (1997). From entrepreneurship to entreprenology. Retrieved from http://web.hec.ca/creationdentreprise/CERB Backup-12-mai-2008/pdf/1997- 05EPIEntreprenology.pdf

İraz, R. (2005). Entrepreneurialism and small and medium sized enterprises in the context of creativity and innovation. Konya: Çizgi Publications.

Istanbul Technical University (ITU). (1994). First Conference on Turkish University and Industry Cooperation. November 4-5, İstanbul.

Karadeniz, O. (Ed.). (2007). On the way to EU: Education in Turkey and human capital. Gazi Publications.

Karagül, M. (2003). The relationship of the human capital with the economic growth and its effective usage. Journal of Faculty of Economics and Administrative Sciences, 5, 79-90.

Kibritçioğlu, A. (1998). The determinants in the economic growth and the importance of the human capital in the new development models. Ankara University Journal of Social Sciences, 53(1-4), 207-230.

Kuratko, D. F., \& Hotgetts, R. M. (1985). Entrepreneurship: A contemporary approach (4th ed.). The Dryden Press.

Peneder, M. (2009). The meaning of entrepreneurship: A modular concept. Journal of Industry, Competition and Trade, 9(2), 77-99.

The symposium on entrepreneurialism in Muğla University. (2013). Retrieved from http://girisimcilik.mu.edu.tr

Yumuşak, İ. G., \& Tuna, Y. (2002). The human capital index as the indicator of the development and an evaluation on Turkey. University Journal of Faculty of Economics, 52(1), 1-26. Retrieved from http://www.journals.istanbul.edu.tr/iuifm/article/ view/1023007163/1023006681 